\title{
Impact of In-Store Music On Customers, Owners, And Employees
}

\author{
Lovish Bandwal ${ }^{1}$, Tripti Singh ${ }^{2}$ \\ Indian Institute of Information Technology, Design and Manufacturing, Jabalpur, India
}

\begin{abstract}
In this study, the research focused on enhancing the customer music listening experience in retail stores. In many stores, owners play songs according to their mood and liking. The wrong music selection affects the experience of customers and employees. Also, there cannot be a single parameter to select songs. The song selection depends upon various factors like age, mood, store profile, etc.

Udaipur was selected for this research, fashion retail stores from multi-brand stores to locallyowned shops in Celebration Mall. In this research, a user-centric design process was used to understand the behavior of customers and employees on music, time spent, and buying behavior. To understand the problem, user observations, interviews, surveys, shadowing, etc. were used. In the existing scenario, local stores do not focus on the importance of music and proper song selection suited for their stores. Analyses revealed that customers spent more time and purchased more when they were exposed to unfamiliar songs.
\end{abstract}

Keywords: Music; Retail store; Consumer behavior; Customer experience; Sales 